\title{
Religion, State, and Law: Constitutional Limits of Islamic Law in National Law in Indonesia
}

\author{
Muhammadun $^{1}$, Oman Fathurohman ${ }^{2}$, Ferry Muhammadsyah Siregar ${ }^{3}$ \\ \{muhammadunabdillah77@gmail.com ${ }^{1}$,omanfathurohman2@gmail.com² \\ ferry.m.siregar99@gmail.com² \\ ${ }^{1,2,3}$ IAI Bunga Bangsa Cirebon
}

\begin{abstract}
Islamic law or Sharia law has universal values. The implementation of Islamic law is substantially open to the opportunity to apply universal values of Islam, however, the implementation of Islamic laws in the national legal system is still limited in a number of laws. This study reveals the construction and reality of Islamic legal products in the frame of national law in Indonesia. This research uses a qualitative paradigm, a religious law approach, and an interdisciplinary study. The results show that indirectly, universal teachings of Islam such as the protection of human rights have been listed in the Indonesian constitution, although they do not use religious language. Derivation of these human rights can be carried out at the level of legislation such as the Marriage Law and Religious Courts. While the desire to make Indonesia as an Islamic state does not receive recognition in the constitution, bearing in mind that the Indonesian state is not an Islamic state, but a law state based on Pancasila which always accommodates the diversity of cultural, racial and religious values systems for Indonesian people and society.
\end{abstract}

Keywords: Religion, Islamic law, Constitutional law, National law, Indonesia.

\section{Introduction}

According to the constitutional system, Indonesia is a nation that consists of geographical territories with diverse tribes, races, cultures, and religions, which requires certain basic rules to legally protect the mutual rights and interests of its citizens. These rules are extracted from the value system to accommodate the interests of citizens. It is a form of "mutual agreement," in accordance with the modern state administration known as the constitution, which has the ability to prevent power from being arbitrarily, thereby guaranteeing the rights of citizens [1].

Furthermore, a collective agreement is stipulated into five basic principles of the state, and this is referred to Pancasila. According to recorded history, Pancasila is the outcome of lengthy discussions and polemics that occurred between people from different religions. It needed to be acknowledged that the ethnic, cultural, and religious diversity of every citizen is inseparable from certain interests, such as practices or teachings of the various religions, as well as making it the basis of the state.

However, because the majority of the citizens are Muslims, they aspire to make Islam the basis of the states, however, this struggle tends to always experience "failure." Therefore, there are at least two important periods that mark these struggles. The first is associated with the emergence of the 1945 constitution. The Muslim community has not succeeded in making 
Islam the general religion, instead it has received recognition of implementing its laws as stipulated in the Jakarta charter. This was formulated during the preamble of the constitution and was endorsed by the Investigating Committee for Preparatory Work for Indonesian Independence (BPUPKI). Many interests and considerations were made in accordance with the fact that Indonesia is not an Islamic state, rather it practices Pancasila. The existence of the Jakarta charter was abolished during the preamble of the 1945 constitution by the Preparatory Committee for Indonesian Independence (PPKI).

The second period that marked this struggle was the election victory from 1955-1959. Although the Muslim community fought again through the constituent assembly, it failed and this led to the creation of the Presidential Decree in July 5, 1959, and the dissolution of the constituents. Therefore, the 1945 constitution was reenacted [2].

The failure of Muslim community to make Indonesia an Islamic state, led to incorporation of the fundamental teachings into the constitution. However, the law was enacted in Pancasila practicing states with guaranteed protection according to the 1954 constitution, paragraph 1 of article 29. However, the practice of Islamic law is only limited to the legislative level and not practiced at the constitutional. Law Number 1 of 1974 on marriage, and the Presidential Instruction Number 1 of 1991 are in accordance with Islamic law. The public law associated with the interests of people has not been implemented in many provinces due to certain religious teachings. However, the Sharia court (Mahkamah Syar'iyah) expanded its jurisdiction and implemented the Islamic law in the Ache Province [3, 4].

Here is some previous research relevant to this topic. Erwin Akhyerdiev and Alexander Ponomarev in their "Religion as Factor in Formation of Law: Current trends" consider the most prevalent religions in present-day society such as Hinduism, Christianity, Islam, and Buddhism and the way in which these religions influence legislation of India, Russia, Thailand, the United Kingdom and Muslim states. Furthermore, the author researches relationship between religion, law, and morality to reveal theoretical and practical links between religion and law. In conclusion, the authors note that the search for the rule we are looking for is not absolute, and many lawyers denied the very possibility of its existence. However, the authors come to the conclusion that complete denial of religious determinism of law restricts the range of possible tools for studying law formation [5].

John Witte in John Witte explained the American constitutional experiment on religious freedom in his book "Religion and the American Constitutional Experiment: Essential Rights and Liberties." According to the book, the First Amendment was a synthesis of two theological beliefs and political calculations of the eighteenth-century American founders that incorporated six interdependent principles: freedom of conscience, right to sport, religious equality, plurality of confessions, disestablishment of religion, as well as the separation of church and state. However, the nuances and balance of these six principles are often lost in the current interpreters of the First Amendment. Therefore, John supported the return of a principled approach to freedom of religion in the American founders' era and the modern international human rights movement. He used these principles to analyze the independence movement and legal freedom over the past two centuries. John further illustrated the importance of his principled approach by analyzing thorny contests on tax exemptions for religion, the role of religion in public schools, and others [6].

The Boisi Center Papers on Religion in the United States titled "Separation of Church and State" stated that religious beliefs and practices are animatedly existent in the United States despite the separation of church and state. This paper is associated with the history and current controversy regarding the disestablishment of religion. It also explains how the constitutional structure of the American government influences religious freedom. Furthermore, surveying 
some of the most important Supreme Court cases relating to religion provided an overview of freedom of worship in the United States [7].

Meanwhile, Larry Catta Backer, in his book "The Crisis of Secular Liberalism and the Constitutional State in Comparative Perspective: Religion, Rule of Law, and Democratic Organizations of Religion Privileging States," examined the issue of "the return" of religion from a comparative constitutional perspective. The main premise is that institutional religion is protected and involved in politics through which it seeks to harmonize the institutional state. Furthermore, the resulting system tends to be more favorable to the associated religion than its political opponents. This book implies that the basic premise of liberal society is understood and applied in the rule of law, direct democracy, general freedom, protection of foreigners, and approaches to the interpretation of constitutional policies [8].

Supriyanto Abdi, in his work "Understanding Religion-State Relations in Muslim Societies: Beyond Essentialist and Secular-Liberal Narratives," stated that scholars had offered a different story in the debates on the religion-state of Muslims worldwide, which are determined by specific essential cultural, religious or civilized characteristics. Another main root of the conflicting analysis is the differing assumptions on the extent to which the discourse of religious-state relations needs to be limited to their secular-liberal character. Abdi reviewed the debate on religious-state relations in the Muslim world due to the two main roots of this dispute. He started with a critical examination of the cultural essentialist approach and its limited analytical value in the discussion of religious-state relations in the Muslim world. This was followed by examining the dominant secular-liberal narrative of the state-religion and their problematic projections. Finally, this book provides an overview of internal debates on the issue of religious-state relations, with a more specific focus on the extent to which secular liberal discourse is contested or critically adopted in the Muslim societies [9].

The urge to use Islamic as the basis of the constitution, by Muslims as stipulated in the 1945 constitution was restricted due to the practice of Pancasila, which means belief in God. Conversely, there was a gap in the limitations to implement Islamic teachings, and it is limited to the substantive value. This study analyzes some of the reasons associated with the inability of the constitution to utilize Islamic law and the limitation of its teachings. Therefore, in order to respond to the issue of its implementation in the country, this research is focused on the concept of the constitution, national legal sources, and the various forms of Islamic strategies in the bid to execute it within the framework of the national law. The purpose of this study furthermore was to describe the opportunities involved in the constitutionalisation of Islamic law into the national legal system in accordance with the concept of a state constitution based on the ideology of Pancasila. Further investigation was conducted by employing the descriptive-analysis-response in accordance with the central theme, which is the main focus of this study.

\section{Discussion}

\subsection{Constitution: A Definition}

The term constitution originated from the French word constituer, which means form, compile or declare a state. It is pronounced as constitution in English, and it is derived from two Latin words, cume (together) and statuere (standing, establishing something). The singular form of constitution simply means to establish things together, while its plural form constitutions are everything that has been determined. According to the Big Indonesian Dictionary (KBBI), it is defined as all the provisions and rules relating to the state 
administration, such as the fundamental law which guides the nation in exercising its power. In addition, constitutional refers to acts or actions exhibited by all the citizens and rulers which are in accordance with the fundamental principles of the law. Constitutionalism is also defined as an understanding concerning the limitations of power and protection of the rights of the citizens through the constitution [10]. In a technical context, it is defined as a state ideology that emphasizes or guarantees the protection of human rights while limiting its power to national institutions that protects the rights of citizenship [11].

Constitutionalism consists of two main elements. The first is the protection of human rights in accordance with a detailed description of the various types in the constitution. Secondly, the system of government and state institutions that has the authority to protect human rights in accordance with the clear limits of the power and possess [12]. The meaning of the word constitution under the context of forming or compiling shows that the definition of the term is obtained from French which refers to a "process" of formation/recognition of a state or government organization. This definition seems easier because it emphasizes more on the process of formation, however, the individual or community that composed it is not known. Its Latin definition is more specific, focusing on efforts to draft law together and not just by a particular group of individuals. The two definitions seem simple and are still multiinterpreted. However, the meaning differs from the big Indonesian dictionary, which refers to it as a technical context, with rules relating to state administration stipulated in the Basic Law as guidelines or instructions in carrying out the government system. The constitutional criteria contained in the big Indonesian dictionary are all written rules. Therefore, it is stated that constitutional rules/laws need to fulfil the written requirements. The consequence is that all unwritten rules are not included in the constitutional criteria. This perception is acknowledged in research conducted by Sri Soemantri that equates the written rule with the basic law [13].

In the Netherlands, the term constitution is not similar to the basic law, however, in Dutch, it is referred to as Gronwet while in Indonesian, ground means basic, while wet means law. According to research conducted by L.J Van Apeldoorn, it was reported that the basic law is part of the written constitution. It was further stated that the constitution contains both written and unwritten regulations [13, 14]. This definition proposed by Van Apeldoorn accommodates the various forms of the constitution adopted in countries that regard unwritten laws such as Britain and Israel.

Nevertheless, the substance of the constitution is established by the practice of state administration. This is traced to the research conducted by Jimly Asshiddieqie, which stated that the British constitution is a building of rules, customs, and habits that determine the composition and power of state organs. It also regulates the relations between state organs and citizens [15]. Asides from the different forms of constitution (written or unwritten), Islamic law is the basic teachings acknowledged by the people to regulate their rights, and form a government that protect the interest of its citizens. This rule under the Indonesian context is contained in the 1945 constitution as the highest law enforcement in the country. Therefore, the constitutional criteria are guided by the written form. They are used in accordance with the state administrative system adopted by the nation.

\subsection{Islamic Law as a National Legal Subsystem}

The 1945 Constitution, guarantees the protection of the rights and interests of the citizens. This formulated law is constitutionally referred to as Pancasila [16]. It is derived from the 
noble values of the country, which regulates the basic principles of citizens' lives without distinction of ethnicity, race, culture, and religion. These noble values were derived from the diversity of tribes, cultures, and religions to govern public interests, which are subsequently formulated in the national legal system. Islam is one of the numerous religions in Indonesia. It plays an important role in the development of the national legal system by ensuring that the teachings are part of the system. This effort does not make or include it in the constitution of the Pancasila because it is a modern nation, and it inherits fundamental philosophical values that are upheld on the basis of constitutional normative, contained in the 1945 constitution. The fundamental values consist of the philosophy of life (Weltanschauung) and the nation (Pancasila), which is based on the noble desire of the citizens to live freely in order to achieve prosperity [17].

These philosophical and constitutional mandates are imperative, binding, or forcing everything within the jurisdiction (sovereignty) of the law to be faithful, uphold peace, practice, inherit and preserve civilization as well as the obligation to defend the state. Therefore, there is no citizen, not even the state institutions and products, as well as government officials and leaders that are not bound to be loyal to these mandates since the inception of the nation's independence and to date.

Pancasila, acts as the main source of law for all Indonesians, it is oriented to provide a sense of justice and legal awareness in the community based on the philosophy of life and personality of the citizens. Generally, the rules that are made and formulated need to comply with the basic principles oriented towards the protection of people and guarantee social justice. In accordance with the above principles, the main source of the constitution creates methods or limits that need to be observed in developing national law [18].

Firstly, the law made is directed at the integration of the nation both territorially and ideologically. This method is derived from the formulation of the 1945 constitution, which is protecting the entire people and their homeland. Secondly, the formulated law needs to be in accordance with the principles of democracy and monocracy through procedures/mechanisms such as transparency and accountability in accordance with the basics of the legal philosophy. Thirdly, the formulated law needs to guarantee social justice by providing protection to the "weak" people in the face of a "powerful" society. Fourthly, guaranteeing religious freedom that upholds the values of religious tolerance. The state guarantees freedom of worship in the sense of protecting the various religious groups in every society. It is regulated in the legislation, which does not enact certain religious laws [12].

Freedom of worship in the Pancasila state has a positive meaning, which is the guarantee to carry out religious orders and protection of citizens that practice their religion. This freedom is not intended as that of America, that is permits atheism and anti-religious propaganda [19].

\subsection{Islamic Law: From Religious Norms to Legal Norms}

The teachings of Islam revealed to humanity by Allah are useful and intended to provide benefits to the entire human race. This is observed in the universal teachings of rahmatanlil 'alamin which is part of the main ideas of Islamic law known as the principle of Malahat oriented towards the benefits and interests of humanity in accordance with development [20].

The universal principles are the teachings on justice (QS an-Nisa': 135), deliberation (QS al-Syuara: 38), recognition and protection of human rights (QS al-Isra': 70), equality before the law (QS al-Hujurat: 13), peace (QS al-Baqarah: 208), tolerance (QS al-Baqarah: 217), 
mandate (QS an-Nisa': 58), and welfare (QS al-Ma'arij: 24-24) [21]. These principles are the basic teachings that need to exist in any government or constitution. They are still used as the standard of religious or moral norms. However, they are not positive legal norms that have sanctions. Therefore, it is necessary to convert religious norms to legal rules by redefining the general teachings in accordance with the theory and fiqh principles. The results of this formulation are referred to as middle norms (intermediate norms). They serve as a link for religious norms with concrete legal rules, for example, the principle of justice in Islamic inheritance [22].

The next step is to incorporate the intermediate laws into the concrete legal norms as contained in the legislation. In addition, changing religious standards to authorized laws are accompanied by constitutional sanctions contained in the positive legal norms. It is necessary for the rule of law that is made to bind all citizens together and also obtain firmness in legislation.

\subsection{Political Negotiations: Strategies Towards the Constitutionalization of Islamic Law}

The effort to implement Islam as a recognized legal norm in the constitution provides a new nuance to the struggle of the Muslims as they constitute most of the communities. The desire to make Islam the basis of the nation is impossible today because the debate concerning the state ideology was concluded in the early era of independence [23]. Pancasila is defined as the cultural, racial, and religious system However, Muslim partisans decided to choose a different way. The consensus of the diversity is the enactment of three legal systems adopted by the people in accordance with their classification. The three legal systems are the Islamic, customary, and western laws. As a form of compromise these systems, A. Qodry Azizi offers to combine the Islamic, customary, and western laws [16, 24]. Conversely, Moh. Mahfud MD offered a legal, political approach that serves as an alternative solution for Muslims that want to implement the teachings of Islam in the country [16].

Moh. Mahfud MD stated the importance of Muslims to conveying ideas or aspirations through the political system in accordance with the teachings of Islam that teaches people to participate in politics. Firstly, they need to live in an organization or system of government in order to be able to convey their rights and beliefs as citizens. Secondly, Islam which is a religion that governs the lives of people, is not only limited to the problem of Mahdhah worship. However, it is also restricted to that of Ghairu Mahdhah worship (muamalah in a broad sense) that covers all aspects of life, including politics. Thirdly, it is a universal religion that urges Muslims to uphold the right and forbid the wrong (amar ma'ruf and nahi munkar) in order to benefit the entire nature (rahmatan lil 'alamin) [12].

The three arguments stated above by Moh. Mahfud MD provides a description that the desire to implement the practice of Islam through a political approach leads to the indigenous lization of its teachings. The forerunner of the political approach that commands Muslims to implement Islamic religion is amar ma'ruf nahi munkar. According to Fazlur Rahman, the ideology of amar ma'ruf nahi munkar is only to create a society. This command forms a moral obligation for the Muslims which serve as a binding of collective responsibilities [25]. Subsequently, there is a different view in understanding the substance of the command to uphold the amar ma'ruf nahi munkar among Muslims, particularly those in the country. 
On the contrary, to uphold the amar ma'ruf nahi munkar, it is necessary to have the power to implement it and ensure it is carried out properly. The consequence of this view is that the presence of the state as a symbol of power is assumed to be needed as the formal foundation in upholding religious orders. Conversely, Muslims feel that the implementation of amar ma'ruf nahi munkar does not need state power which is identically formalistic, rather they believe in the spirit and values of the substance contained in it. These values emphasize universal teachings (rahmatan lil 'alamin) [12].

In practice, this effort presents two implementation models, formal and substantive models. Firstly, the political approach is structured formally. According to the book titled Building Legal Politic, Upholding the Constitution written by Moh. Mahfud MD stated that the struggle of Muslims through a formalistic-structural political approach is directed at efforts to uphold the Islamic state and the Basic Law as the official constitution of the nation. The existence of an Islamic state serves as a legitimacy which is a requirement for the implementation of amar ma'ruf nahi munkar [12]. Secondly, the political approach is culturally-substantive. Its effort is to internalize Islamic values into written legal norms in a number of statutory regulations in the nations' constitutional system. The Cultural aspects emphasize the inculcation and spread of substantive values of Islamic teachings without having to use the formal symbols of Islam [12].

During the Reformation era, the teachings of the substance into the nation's legal system are carried out through political, academic and religious organizations. Additionally, the cultural approach emphasizes the core values contained in the teachings of Islam, which provides broader opportunities to implement the values of both private and public Islamic teachings. The implementation of Islamic law through a cultural approach becomes more meaningful, assuming its legislation contains the values of the required teachings. The religious principles believed to be culturally normative and this reflects in the daily attitudes of the Muslim community. The values of these teachings include private (diyani) and public laws which are included in the national legal system (qadha'i) [26]. The Islamic law implemented in the national legal system has a broader scope and regulates issues associated with the society on freedom. For example, issues associated with worship such as prayers and fasting, rules for greeting in public, how to enter public places, visiting procedures, and belief.

The individual aspects of Islam tend to be regulated by the state when the problems of worship, character, and personal beliefs are related to the rights and obligations of others. For example, the problem of zakat and hajj needs to be regulated by law because they involve management, distribution (zakat) and use of public funds, in solving legal problems. Furthermore, it regulates public interests on banking, trade, endowment, health, relationship between citizens and other countries, as well as public issues that involve the authorities. Without the implementation of these legislative rules, difficulties tend to arise.

Conversely, in terms of authority, the Indonesian Ulema Council (MUI) have the right to carry out division of duties, without separating religious power from the state, with legal issues involving individuals (diyani laws). Additionally, issues relating to the public interest are the rights of the government, therefore, the judiciary decides on the applicable laws and regulations. These problems which are regarded as individual aspect (diyani) become a public issue that requires the intervention of the authorities (qadha'i). 


\section{Conclusion}

The constitutionalisation of Islamic law into the national legal system is achieved through an informal political approach and open to opportunities consisting of various universal teachings. The universal Islamic teachings associated with the protection of human rights have long been listed in the constitution. Its derivation is carried out at the level of legislation such as marriage and religious court. However, the desire to convert Indonesia to an Islamic state is not recognized in the constitution, rather its laws are in accordance with the ability to accommodate diversified cultural, racial, and religion of all people. However, the opportunities to implement Islamic law as mandated in the 1945 constitution tend to be carried out only at the legislative level or presidential instructions. At this level, efforts to include the values of Islamic teachings seem more easily accepted than at the constitutional level.

\section{References}

[1] Soetanto Soepladhy. Meredesain Konstitusi. ttp. : Kepel Press, 2004. p. 23

[2] Ahmad Syafi'I Ma'arif, Islam dan Masalah Kenegaraan: Studi Tentang Pencaturan dalam Konstituante, Jakarta: LP3ES, 1985.

[3] Al Yasa Abubakar. Penerapan Syariat Islam di Aceh: Upaya Penyusunan Fikih dalam Negara bangsa. Banda Aceh: Dinas Syariat Islam Aceh, p. 2, 2008.

[4] Moh. Fauzi. Legislasi Pelaksanaan Syariat Islam di Provinsi Nanggroe Aceh Darussalam: Pergumulan Sosto-Politik dan Tinjauan Hukum Tata Negara. Thesis Program Pascasarjana IAIN Ar-Raniry Banda Aceh, p. 15-16, 2009.

[5] Erwin Akhyerdiev \& Alexander Ponomarev. "Religion as Factor in Formation of Law: Current trends". SHS Web of Conferences, 50, 01024. 2018. https://doi.org/10.1051/shsconf/20185001024.

https://www.researchgate.net/publication/328237087_Religion_as_Factor_in_Formation_o f_Law_Current_trends. Accessed on July 1, 2020.

[6] Witte, John. Jr. Religion and the American Constitutional Experiment: Essential Rights and Liberties. Westview Press, 2000.

[7] The Boisi Center Papers on Religion in the United States in "Separation of Church and State" in https://www.bc.edu/content/dam/files/centers/boisi/pdf/bc_papers/BCPChurchState.pdf, accessed on July 1, 2020.

[8] Backer, Larry Catta. "The Crisis of Secular Liberalism and the Constitutional State in Comparative Perspective: Religion, Rule of Law, and Democratic Organization of Religion Privileging States.” Cornell International Law Journal, Vol. 48, No 1. 2015.

[9] Supriyanto Abdi. "Understanding Religion-State Relation in Muslim Societies: Beyond Essentialist and Secular-Liberal Narratives." Indonesian Journal of Interdisciplinary Islamic Studies (IJIIS), Vol.1, No.1. September, 2017.

[10] Tim Penyusun Kamus. Kamus Besar Bahasa Indonesia Edisi III. Jakarta: Balai Pustaka, p. 521. 1991.

[11] Moh. Mahfud MD, Aktualisasi Hukum Islam di dalam Masyarakat yang Plural. Kumpulan Makalah sebagai Bahan kuliah pada Program Doktor Konsentrasi Ilmu Hukum dan Pranata Sosial Islam UIN Sunan Kalijaga Yogyakarta. p. 28, 2016

[12] Moh. Mahfud MD. "Aktualisasi Hukum Islam di dalam Masyarakat yang Plural." Kumpulan Makalah sebagai Bahan kuliah pada Program Doktor Konsentrasi Ilmu Hukum dan Pranata Sosial Islam UIN Sunan Kalijaga Yogyakarta. p. 28, 2016. 
[13] Dahlan Thaib, dkk. Teori dan Hukum Konstitusi, Cet. 9, Jakarta: Raja Grafindo Persada, p.8. 2011

[14] Sri Soemantri. Prosedur dan Sistem PerubahanKonstitusi. Bandung: Alumni, p.1. 1987.

[15] Jimmy Asshiddieqie. Konstitusi dan Konstitusionalisme Indonesia. Jakarta: Sinar Grafika, p. 16-17, 2010.

[16] Moh. Mahfud MD. Membangun Politik Hukum, Menegakkan Konstitusi, Cet. III. Jakarta: Raja Grafindo Persada, p. 281, 2012.

[17] Padmo Wahjono, "Asas Negara Hukum dan Perwujudannya dalam Sistem Hukum Nasional," dalam M. Busyro Muqoddas, dkk (peyn.), Politik Pembangunan Hukum Nasional, Yogyakarta: UII Pers, p. 43, 1992.

[18] Moh. Mahfud MD. Pedoman Hukum Tata Negara Pasca Amandemen Konstitusi. Jakarta: LP3ES, p. 8, 2007.

[19] Muhammad Tahir Azhary. Negara Hukum: Suatu Studi Tentang Prinsip-Prinsipnya dilihat dari Segi Hukum Islam, Implementasinya pada Periode Negara Madinah dan Masa Kini Cet. IV. Jakarta: Kencana, p. 93, 2010.

[20] Jasser Auda. Membumikan Hukum Islam Melalui Maqosid Syariah: Pendekatan Sistem. terj. Rosidin dan Ali Abd el-Mun'im. Bandung: Mizan, p. 60, 2015.

[21] Juhaya S. Praja, Filsafat Hukum Islam. Bandung: Pusat Penerbitan UNISBA, p.6777, 1995.

[22] Syamsul Anwar. Hukum Perjanjian Syariah: Studi tentangTeoriAkad dalam Fikih Muamalat. Jakarta: Raja Grafindo Persada, p.12-15, 2007.

[23] Endang Saefuddin Anshari. Piagam Jakarta 22 Juni 1945: Sebuah Konsensus Nasional tentang Dasar Negara Republik Indonesia (1945-1949). Jakarta: Gema Insani Press, p. 9-10, 1997.

[24] A. Qodry Azizi. Hukum Nasional: Elektisisme Hukum Islam dan Hukum Umum. Bandung: Teraju Mizan, p.8, 2004.

[25] David Little, dkk. Kebebasan Aagama dan Hak-hak Asasi Manusia: Kajian Lintas Kultural Islam-Barat,terj. Riyanto. Yogyakarta: Pustaka Pelajar,p.107. 2007.

[26] Rifyal Ka'bah, Hukum Islam Di Indonesia: Perspektif Muhammadiyah Dan NU, Jakarta: Universitas Yasri, p. 56-59, 1999. 